DANILO ŠARENAC, istoričar, MA

Beograd, Grge Andrijanovića 6b

UDK 355.082.4:061(497.1)"1919/1941"

\title{
UDRUŽENJE REZERVNIH OFICIRA I RATNIKA 1919-1941
}

\begin{abstract}
APSTRAKT: Članak se bavi organizovanjem i aktivnostima dela veterana bivše srpske vojske u okviru Udruženja rezervnih oficira $i$ ratnika. Rad ove organizacije podrazumevao je brigu za materijalna prava i status, pre svega rezervnih oficira, ali i borbu za očuvanje ratnih uspomena i tradicija na ratove 1912-1918. U periodu uspona (1922-1933) Udruženje je ostvarilo samo deo svojih ciljeva, a način na koji je rukovođeno ovom organizacijom doveo je do velikih unutrašnjih sukoba i krize celokupne organizacije. Period do marta 1941. prošao je u pokušajima da se rezervni oficiri ponovo organizuju, ovoga puta sa većim naglaskom na materijalnom pomaganju članstva umesto očuvanja sećanja na svoje ratne doživljaje. Ipak, ni članovi Udruženja nisu uspeli da značajnije izmene materijalni položaj bivših ratnika.
\end{abstract}

Ključne reči: Prvi svetski rat, Udruženje rezervnih oficira i ratnika, ratni veterani

Predrag Milojević, dopisnik lista Politika iz Nemačke, izvestio je 1930. godine o neobičnom postupku bivšeg artiljerca Johana Lautkina, koji je sa svog berlinskog balkona ispaljivao granate unaokolo, iz topa koji je sam napravio, verujući da bombarduje Pariz. ${ }^{1}$ Ovo je radikalan primer da Svetski rat ne treba sagledavati samo u domenu ljudskih žrtava, stepenu materijalnog uništenja ili političkih promena, već i u okviru demobilizacije ljudstva i pokušaja povratka bivših boraca u mirnodopski život. Nekadašnji ratnici suočavali su se sa različitim

${ }^{1}$ „Čovek sada ležu u duševnoj bolnici, a top u policiji. Ali između ovog čoveka i topa leži još nešto bolno i tragično, što ne spada u nadležnost ni policije ni duševne bolnice, već predstavlja tragiku našeg doba. Jedna portirka iz kuće na koju je pala granata ispričala je policiji šta je osećala kad je počelo bombardovanje. Prosta i priglupa žena pomislila je u prvom strahu da su počele da padaju granate koje su ispaljene još za vreme rata na frontu, pa su zbog nečeg sve do sada lutale kroz vazduh.“ - Predrag Milojević, Čovek s topom, NIN, 17, 14. maj 1967, 853, 24. U domenu psihičkih posledica rata karakterističan je i slučaj Velike Britanije u kojoj je došlo do značajnog uspona spiritualizma među porodicama poginulih vojnika. Jedan od najpoznatijih posleratnih spiritualista bio je Artur Konan Dojl, koji je u ratu izgubio sina, brata i zeta. - Jay Winter, Sites of memory, sites of mourning. The Great War in European cultural history, Cambridge 1995, 58-61. 
problemima, ${ }^{2}$ počev od borbe za svoj materijalni status, ugled kao i za ostvarivanje zakonskih prava, pa do borbe sa različitim, među njima i sasvim novim bolestima koje su stečene kao rezultat dugog ratnog iscrpljivanja. ${ }^{3}$ Istovremeno, nekadašnji vojnici su bili i jedna nova politička snaga. ${ }^{4}$

U Kraljevini Jugoslaviji Udruženje rezervnih oficira i ratnika je predstavljalo najmoćnije veteransko udruženje. Razgranate aktivnosti ove organizacije omogućavaju proučavanje ne samo dugotrajnosti borbe jugoslovenske države sa najrazličitijim ratnim posledicama, već i ideološkog značaja srpskih ratničkih tradicija u novonastaloj državi. Na mnogo načina neuspeh Udruženja u ostvarivanju njegovih ciljeva podudarao se sa porazom jugoslovenske države u rešavanju niza pitanja koja su mučila veterane srpske vojske.

Organi Udruženja bavili su se ostvarivanjem tzv. ratničkog zakonodavstva, zatim banjskih i drugih zdravstvenih povlastica, kao i transportnih olakšica. Isto tako, posebnu celinu činile su aktivnosti u domenu očuvanja sećanja na ratne događaje, dok se političko delovanje predstavnika ove organizacije ogledalo pre svega u propagiranju unutrašnjeg državnog jedinstva, kao i u neprestanoj budnosti nad bivšim neprijateljima.

\section{Organizovanje bivših ratnika u periodu 1919-1933}

Udruženje rezervnih oficira i ratnika je okupljalo samo manji deo ratni$\mathrm{ka}$, i to pre svega oficira bivše srpske vojske. Međutim, iako malobrojna, ova grupa je značajno uticala na rešavanje ratničkih pitanja, kao i na selekciju ratnih uspomena. Prema svom imenu organizacija je obuhvatala i obične vojnike, ali u stvarnosti borba za prava te kategorije boraca nije spadala u prioritete ovog, preovlađujuće elitnog udruženja. Ideja o organizovanju rezervnih oficira javila se odmah posle Prvog balkanskog rata. Ipak, stvaranje udruženja je odloženo usled izbijanja novog, bugarskog, rata. Na taj način odsustvo bilo kakvog značajnijeg predaha tokom sedam godina ratovanja dovelo je do neprestanog odlaganja formiranja ove organizacija, sve do 1919 . godine. ${ }^{5}$

${ }^{2}$ Kao jedan od drastičnih primera srpskog demobilisanog ratnika može se navesti primer vojnika Petronija Marušića koji je iz rodnog sela otišao 1912. godine da bi se iz rata vratio tek 1920. Po povratku je pored pet grobova svoje dece, zatekao i sopstveni nadgrobni spomenik podignut od strane porodice, koja je verovala da je Petronije do tada morao stradati u ratu. - Исидор Ђуковић, Рудничани и Таковци у ослободилачким ратовима Србије 1912-1918, Горњи Милановац $2005^{2}$, 3. Верује се да је у Светском рату укупно учествовало око 70 милиона војника. - Губичи у европском рату, Ратнички гласник, 4, VII, 1925, 219.

Harvard 2001, 21-71.

3 Ben Shephard, A War of Nerves. Soldiers and Psychiatrists in the Twentieth Century,

${ }^{4}$ Antoine Prost, Les anciens combattants 1914-1940, Paris 1977; Gerd Krumeich, L'impossible sortie de guerre de l'Allemagne, Sortir de la Grande Guerre. Le monde et l'après-1918, Paris 2008, 145-158.

${ }^{5}$ Rezervni oficiri su se neformalno sastajali tokom 1913. godine u kafani Kasina. Značajno je istaći da pored izbijanja novog rata, ni nadležne vlasti nisu izašle u susret pokušaju da se for- 
Pre nego što je Udruženje rezervnih oficira i ratnika definitivno dobilo svoj oblik, ono je prošlo kroz nekoliko etapa praćenih sukobima sa organizacijama sličnog tipa, ali i borbom unutrašnjih frakcija. Prvi naziv Udruženja glasio je Udruženje rezervnih oficira i obveznika činovničkog reda. Kao takvo osnovano je 20. jula 1919. godine. ${ }^{6}$ Tokom 1921. godine Udruženju se priključio najveći deo članova i odbora druge organizacije, koja nije opstala na javnoj sceni - reč je o Udruženju ratnika. ${ }^{7}$ Sledeći korak u ratničkom organizovanju bilo je osnivanje Saveza boraca za jedinstvo i slobodu koji je trebalo da predstavlja zajednicu svih ratničkih udruženja i samim tim snažnijeg borca za prava veterana. Ipak, pokušaji osnivanja Saveza u ovom periodu doživeli su neuspeh. ${ }^{8}$ Nije jasno zašto je ova akcija ostala bez rezultata, ali je najverovatnije u pitanju ljubomorno čuvanje sopstvenih tradicija, već poznatih srpskih predratnih organizacija poput Narodne odbrane ili nekoliko četničkih organizacija koje je takođe trebalo da budu članovi Saveza boraca.

Konačno, 4. marta 1922. došlo je do spajanja Udruženja rezervnih oficira $i$ obveznika činovničkog reda sa Udruženjem ratnika, čime je stvoreno Udruženje rezervnih oficira i ratnika. ${ }^{9} \mathrm{Na}$ čelu Udruženja u ovom periodu nalazili su se najpre dr Čeda Marjanović, zatim major Vasa Danilović, dok je mesto potpredsednika pripalo rezervnom pešadijskom majoru Milanu Đ. Radosavljeviću, osobi koja će nešto kasnije u potpunosti obeležiti čitavu jednu deceniju u radu Udruženja. ${ }^{10} \mathrm{Sa}$ Radosavljevićevim dolaskom može se govoriti o potpunoj stabilizaciji ove organizacije, iako će kasnije izaći na videlo sve manjkavosti njegovog rada. ${ }^{11}$

\section{Program Udruženja}

U navedenom periodu (1919-1922) Udruženje je lutalo i po pitanju svog ideološkog usmerenja, kao i svojih najprečih ciljeva. Ipak, u mnoštvu tema jasno se razaznaje njih nekoliko. Na prvom mestu ističe se ideja čuvanja Otadžbine, odnosno zaštita stečenih tekovina i njihova neokrnjena predaja mlađim naraštaji-

mira Udruženje odbijanjem ponuđenih pravila Udruženja. - Историја нашег Удружења, Ратнички гласник, I, 1, 1922, 5; Извештај са годищњег збора Удружења рез. Официра и ратника, Ратнички гласник, 6, IV, 1927, 122.

${ }^{6}$ Историја нашег Удружења, Ратнички гласник, I, 1, 1922, 6.

${ }^{7}$ Spajanje je izvršeno na zboru 8. maja 1921. godine. Za ovaj period karakterističan je sudski spor sa blagajnikom ugašenog udruženja koji je odbio da preda blagajnu Udruženju rezervnih oficira. - Извештај Управног одбора, Ратнички гласник, I, 1, 1922, 32.

${ }^{8}$ Извештај Управног одбор“, Ратнички гласник, I, 1, 1922, 33.

${ }^{9}$ Измене правила, Ратнички гласник, I, 2, 1922, 69.

${ }^{10}$ Историја нашега Удружења, Ратнички гласник, I, 1, 1922, 5.

${ }^{11}$ Radosavljević je izabran na vanrednom skupu Udruženja 8. maja 1921. Istom prilikom za novog potpredsednika je izabran rezervni pukovnik Pavle E. Jurišić. Vanrednost saziva kao i ostavke stare uprave ukazuju da je verovatno bio u pitanju svojevrstan prevrat u okviru ove organizacije. Ostavke su podneli Mihajlo Švabić, Stojan Nikolić i Joca Lazić. - Извештај Управног одбора, Ратнички гласник, I, 1, 1922, 32. 
ma. ${ }^{12}$ Članovi Udruženja su sebe videli kao „zdravu nacionalnu organizaciju“ koja i te kako može da posluži državi, koja je, kako se isticalo, potukla neprijatelje, ali koji su i dalje stajali pred vratima zemlje. ${ }^{13} \mathrm{U}$ opisu spoljnih i unutrašnjih problema predstavnici Udruženja su retko imenovali protivnike, ali su njihove aluzije ipak dovoljno jasne. Tako je veterane pre svega mučio otvoreni revizionizam suseda kao i, uprkos usvajanju Ustava, postojanje hrvatskog, muslimanskog i crnogorskog pitanja. ${ }^{14}$

Pod maskom prijateljstva i bratstva ostavio nam je bio svoj neprijateljski teret i u samoj kući, da nam mučki pritiskuje i razorava ognjišta, na kojima smo se mi sa slavnim pretcima svojim vekovima zapajali samo ljubavlju prema Otadžbini i zagrevali za njenu veličinu i njenu svetlu budućnost. Počeše nas ponova učiti rodoljublju i požrtvovanju, radu i kulturi, čak i oni, koji su daleko od svega toga kao mračna zemlja od jarkoga sunca. ${ }^{15}$

Borba za materijalna prava u prvom redu se odnosila na duplo računanje godina provedenih u ratu prilikom napredovanja u službi ili odlaska u penziju. Istovremeno, tražilo se i izuzeće, za oficire i vojnike, od planiranog smanjenja državnih činovnika. Strah od „redukcije činovnika“ izazivao je pravu paniku među rezervnim oficirima, koji su većinom bili upravo činovnici, a problem bi se uvek iznova javljao jer se svaki stečeni ustupak morao ponovo braniti prilikom promene vlade. ${ }^{16}$ Tokom redukcije državnih službenika 1922. godine otpušten je i jedan od čelnih ljudi Udruženja, Milan Radosavljević. ${ }^{17}$ Suština borbe za „priznavanje ratnih godina“" svodila se na očuvanje člana 282 Finansijskog zakona iz 1922. godine. Član je garantovao duplo računanje godina, to jest 18 meseci, činovnicima koji su bili u ratu. Novi Činovnički zakon ukinuo je ovo pravo, pa je usledila burna intervencija uprave Udruženja kod Državnog saveta i kralja Aleksandra I. ${ }^{18}$ Pitanje zahvalnosti za usluge otadžbini postavilo se, na još zamršeniji način, i u slučaju onih otpuštenih činovnika koji zaista nisu imali školu niti druge uslove za obavljanje posla, ali su imali nesumnjive ratničke zasluge. ${ }^{19}$

Jedno od polja na kome je delovala ova organizacija bila je borba protiv „posleratne atmosfere“. U svojim člancima često su osuđivali ,zabludelu mladež“ koja, prema standardima rezervnih oficirima, nije dovoljno cenila ratničke

${ }^{12}$ Милан Ђ. Радосављевић, Нама реч, Ратнички гласник, I, 1, 1922, 1.

${ }^{13}$ II Редовна Годишња Скупштина Пододбора у Сарајеву, Ратнички гласник, 4, I, $1925,9$.

${ }^{14}$ Ник. Станаревић, Зашто динар пада, Ратнички гласник I, 1, 1922, 15.

${ }^{15}$ Историја намега Удружењ а, Ратнички гласник, I, 1, 1922, 5.

${ }^{16}$ Редукција чиновника, I, Ратнички гласник, 1, 1922, 23.

${ }^{17}$ Исто.

${ }_{18}^{18}$ Ратник, Редукиија чиновника ратника, Ратнички гласник, 3, II, 1924, 33.

19 „Isto tako dobar deo drž. službenika u toku ratova primljen je bez dovoljno školske spreme i zbog toga: što niko od školovanih nije hteo ići u Makedoniju i južne krajeve, gde je u ono vreme igrala glava, i gde su neophodno potrebni bili naši ljudi u koje se imalo vere i pouzdanja.... Mi mislimo da to nije ni pravo ni pošteno ni oportuno. Zašto bez nužde stvarati umni proletarijat i to na ovaj nezgodni način? Bar nezadovoljnicima i bez toga obilujemo.“ - Исто, 34. 
tradicije. Napadao se i materijalizam svake vrste, ,zaraza lakog i brzog bogaćenja“ ${ }^{60}$, ili ,žudnja za vlašću po svaku cenu koja pomračuje um.“ ${ }^{\text {‘21 }} \mathrm{U}$ tom smislu namera bivših ratnika bila je da se vrline koje su vezivane za ponašanje vojske u ratu primene i u mirnodopskim uslovima. ${ }^{22}$

Važan deo aktivnosti Udruženja odnosio se na održavanje živim uspomena na rat, očuvanje imena poginulih i ranjenih, kao i istorije ratova. Objavljivane su prigodne knjige, fotografski albumi, takođe građeni i spomenici, kosturnice ili reprezentativni objekti. Primer rada Udruženja rezervnih oficira i ratnika jedne malobrojne elite na čuvanju ratnih tradicija i selekciji i prenošenja utisaka o događajima iz prošlosti.

Posmatrajući rad Udruženja u ovoj oblasti uočava se i jedna šira ideja: da se istaknu i prenesu dalje one osobine za koje se verovalo da su bile presudne za srpsku pobedu. Jedna od svojstvenosti ratničkog sećanja nekadašnje srpske vojske jeste i veoma znatan broj događaja koje je trebalo obeležavati. ${ }^{23}$ Godišnjice su sustizale jedna drugu, a raspored komemoracija i slavlja neprestano je dopunjavan posmrtnim govorima upućenim umrlim srpskim vojvodama ili generali$\mathrm{ma}^{24}$

Suprotno ratničkoj solidarnosti, stranačka pripadnost ili „partizanstvo“ takođe su pominjani kao obeležja vremena. Oni su označeni kao smrtni neprijatelji veteranske dobrobiti i ,čistote“ ratničkog drugarstva. Vodeći ljudi organizacije isticali su da se partijska osećanja ne smeju unositi na veteranske skupove kao i „da se politički bagaž mora ostaviti pred ulazom“. ${ }^{25}$ Borba za otadžbinu trebalo je da bude suprotnost „nečuvenoj zatrovanosti međupartijskih odnosa“, ili „odvratnoj partijskoj demagogiji“, gde se licitira i trguje. ${ }^{26}$ Međutim, oko 60 članova Udruženja činili su narodni poslanici različitih stranaka, od kojih je, ipak, samo manjina ulagala svoj uticaj kako bi pomogla ratničke zahteve. ${ }^{27}$

Politiku ćemo mi ratnici, nastavio je g. Radosavljević, ostaviti političarima, ljudima čiji je to zanat, ali zato moramo i poručujemo odmah svima i svako-

${ }^{20}$ Историја намега Удружења, Ратнички гласник, I, 1, 1922, 5.

${ }^{21}$ Исто. - Utisak apatičnosti poratnog društva komentarisali su i drugi građani: „Želje su se proširile, ambicije razuzdale, prohtevi se uvećali, i nastala je opšta trka, opšti grabež. Materijaliziralo se sve, ideali se srušili u prah i vodi se kurjačka borba samo o komad hleba..." - Милан Л. Рајић, Свима младима, Препород, 1, I, 1920, 32.

${ }^{22}$ Историја намега Удружења, Ратнички гласник, I, 1, 1922, 5.

${ }^{23}$ Tokom 1925. godine vlada je odustala od obeležavanja 10-godišnjice prelaska preko Albanije zbog više razloga. U toku je bila politička kriza u zemlji, a nije se imalo ni dovoljno novca za značajniju proslavu. Tamošnja srpska groblja su bila još uvek neuređena i razbacana na više strana. Međutim, postojala je i nedoumica treba li obeležavati dolazak na Krf u proleće 1916. ili sam čin povlačenja s kraja 1915. - Одлагање пута на Крф, Ратнички гласник, 4, V, 1925, 159.

${ }^{24}$ Još 1922. godine među pokojnicima nalazili su se kralj Petar i vojvode Putnik i Mišić. - Војвода Живојин Р. Мишић, Ратнички гласник, I, 2, 1922, 50.

${ }^{25}$ II Редовна Годишъа Скупштина Пододбора у Сарајеву, Ратнички гласник, 4, I, $1925,9$.

\footnotetext{
${ }^{26}$ Инвалидско питање, Ратнички гласник, 4, II, 1925, 38-39.

${ }^{27}$ Наша конференција, Ратнички гласник, 4, V, 1925, 134.
} 
me, da nipošto nećemo dozvoliti, da se sa ovom krvlju stečenom državom titra ili eksperimentiše poput ruskih utopista i da se samo preko naših leševa ova država može cepati i deliti. ${ }^{28}$

Tokom 1926. godine uprava Udruženja odlučila je da se više angažuje na širenju svoje organizacije u Hrvatskoj i Sloveniji. Ključni događaj u zaokretu Udruženja ka jugoslovenskom programu predstavljala je izmena Pravila Udruženja iz 1923. godine, ali je tek sa skupom u Zagrebu 24-26. maja 1926. snažnije otpočet rad i u ovim krajevima. ${ }^{29}$ Novousvojeno Pravilo bilo je mnogo prilagodljivije. ${ }^{30}$ Zagrebački skup, na kome je osvećena i zastava Udruženja, uz kumstvo kralja Aleksandra I Karađorđevića, organizovan je u duhu novog motoa Udruženja: „Iznad svih verskih i stranačkih podvojenosti, za Kralja, vojsku i Otadžbinu, za sreću i dobro naroda“. ${ }^{31}$

Promena u strukturi organizacije ogledala se i u redovnom prilivu mladih rezervnih oficira koji nikada nisu služili u srpskoj vojsci. Ukupno posmatrano, organizacija je nastojala da istovremeno deluje na nizu polja, pri čemu je rad na državnom jedinstvu i borbi protiv svih državnih protivnika tekao uporedo sa osnivanjem potrošačkih zadruga i pomaganjem porodica poginulih oficira. ${ }^{32}$

Ovako šaroliku aktivnost podržavao je veliki broj uglednih dobrotvora. Među njima se nalazilo mnoštvo najistaknutijih privrednika, oficira i političara. ${ }^{33}$ Pojedinci su mogli da upišu svoje pretke za dobrotvore, pa je tako Udruženje u svoje ,članove“ uvrstilo i građane koji nisu doživeli Svetski rat. Vidosava Jurišić je tako upisala svog oca Milana A. Pavlovića, bivšeg komandira beogradskog eskadrona u ratu $1876-1877 .{ }^{34}$ Slično, Nikola Pašić je posthumno upisan među članove jer budući da je učestvovao u ratu 1876. godine..$^{35}$ Ovakvim pristupom je, osim što je uzdizan autoritet Udruženja, na još jedan način učvršćivana i veza između različitih etapa oslobodilačkih ratova, koji su time povezivani u jedinstvenu celinu, sa naknadno definisanim ciljem - stvaranjem Kraljevine Jugoslavije.

Među članovima Udruženja nalazili su se ljudi poput dvorskog apotekara Save Mrcalovića, ${ }^{36}$ Dimitrija Ginića, reditelja Narodnog pozorišta, Joce Stojčevića, reditelja iz Novog Sada. ${ }^{37}$ Pored umetnika tu je bilo i lica na visokim politič-

${ }^{28}$ Исто.

${ }^{29}$ Do izmene Pravila članove Udruženja su činili pre svega srpski vojnici sa Solunskog fronta, kao i jugoslovenski dobrovoljci. - Једна задовољена потреба, Ратнички гласник, 4, IV, 1925, 100.

${ }^{30}$ „Te potrebe zahtevale su izmene pravila, i ona je izvršena pre dve godine na taj način što je izmenom pravila omogućen ulaz u organizaciju pod izvesnim uslovima i ostalim rezervnim oficirima nacionalno nekompromitovanim, koji nisu bili srećni da se bore u redovima srpske vojske“. - Исто, 100.

\footnotetext{
${ }^{31}$ Исто

${ }^{32}$ Исто.

${ }^{33}$ Чланови добротвори, Ратнички гласник, 4, I, 1925, 15.

${ }^{34}$ Исто.

${ }^{35}$ Протокол седнииа средишње управе, Ратнички гласник, 6, IV, 1927, 127.

${ }^{36}$ Интервениије и морална помоћ, Ратнички гласник, 4, III, 1925, 74.

${ }^{37}$ Јубилеји и свечаности, Ратнички гласник, 4, III, 1925, 78.
} 
kim pozicijama, poput pomoćnika ministara, Milana Ranisavljevića, u Ministarstvu saobraćaja, ${ }^{38}$ ili dr Stefanovića, pri Ministarstvu prosvete, potom narodnih poslanika predvođenih Ranislavom Agatonovićem i drugih.

Glavni sekretar Udruženja dugo vremena bio je Ljubomir V. Stefanović, rezervni pešadijski major i predsednik Advokatskog udruženja, a u upravi se nalazio i Nedeljko Savić, rezervni artiljerijski potpukovnik i trgovac. ${ }^{39}$ Među članstvom izdvajali su se Solomon Alkalaj, arhitekta Momir Korunović, predsednik Aero-kluba Tadija Sondermajer, direktor filijale Narodne banke u Skoplju Todor Vasojević, rezervni sanitetski potpukovnik Josif Nedok, zatim Mihailo Radović, rezervni sanitetski potpukovnik i upravnik Čačanske bolnice. Pored njih tu su bili i Arčibald Rajs, kao i David Albala. U vreme zenita svoje moći gotovo celokupno rukovodstvo beogradske opštine činilo je upravo najuži krug Udruženja rezervnih oficira i ratnika. ${ }^{40}$

Među predstavnicima Udruženja u Hrvatskoj nalazili su se šef zagrebačke policije, ratni dobrovoljac Josip Klinčić, ${ }^{41}$ predsednik pododbora u Ljubljani bio je Milan Plut, ${ }^{42}$ dok je predsednik pododbora u Zagrebu, Zorčić, 1929. godine postao veliki župan Zagrebačke oblasti. U isto vreme, član Udruženja Milorad Jovanović imenovan je za velikog župana Moravske oblasti. ${ }^{43}$

Kao finansijeri Udruženja isticali su se Francusko-srpska banka, Jadranska banka u Beogradu, Srpsko-amerikanska banka, Prva Hrvatska štedionica, Generalna banka za trgovinu i industriju, takođe i pojedinci poput Benciona Bulija i Đorđa Vajferta. ${ }^{44}$

\section{Kriza i kraj Udruženja 1933-1941}

Udruženje rezervnih oficira i ratnika je do 1933. godine uspelo da ostvari značajan broj svojih ciljeva. Završena je izgradnja Ratničkog doma koji je svečano otvoren, a ostvareni su i uspesi prilikom računanja duplih godina, kao i drugih manjih povlastica. Organizovan je kongres Fidaka ${ }^{45}$ u Beogradu 1929. godi-

${ }^{38}$ Извештај надзорног одбора, Ратнички гласник, 4, III, 1925, 86.

39 Записник седме годишње редовне седнище, Ратнички гласник, 4, IV, 1925, 112.

40 ИАБ, 1027, К-. „Књига записника са седница Управног одбора и Средишне Управе Удружења резервних официра и ратника од 24. 8. 1928 - 2. 8. 1929“, 72, Седница одржана 22. фебруара 1929.

${ }^{41}$ Исто, 112-113.

${ }^{42}$ Милан Плут, Ратнички гласник, 4, IV, 1925, 128.

${ }^{43}$ ИАБ, 1027. „Књига записника са седница Управног одбора и Средишне Управе Удружења резервних официра и ратника од 24. 8. 1928 - 2. 8. 1929“, 72, Седница одржана 22. фебруара 1929. године, ИАБ, 1027. 1924,71

${ }^{44}$ Списак добротвора и утемељивача намег Удружења, Ратнички гласник, 3, III,

${ }^{45}$ Фидак - Fédération Interallié des Anciens Combattants. „Međunarodna federacija ratnika iz savezničkih zemalja“ osnovana je odmah po završetku Svetskog rata. Samo postojanje ove organizacije održavalo je na mnogo načina ratne posledice. Moto organizacije glasio je „Sjedinjeni kao na frontu!“‘. Prvi predsednik Fidaka bio je Šarl Bertran, ujedno njen ključni osnivač. Organiza- 
ne, a predsednik Udruženja Radosavljević je 1930. čak izabran za predsednika te međunarodne ugledne federacije. ${ }^{46}$ Istovremeno, završena je velika kosturnica na Novom groblju, uređeno i prošireno francusko vojničko groblje u Beogradu, kao i niz manjih kosturnica i spomenika širom Srbije. ${ }^{47}$

Ipak, u Udruženju su se dešavali povremeni sukobi posle kojih bi grupa nezadovoljnika po pravilu napuštala Udruženje. Prvi takav slučaj zabeležen je u odnosima sa slovenačkim ogrankom ove organizacije. Iz neutvrđenih razloga, Središnja uprava Udruženja odlučila je da razreši celokupno rukovodstvo ljubljanskog pododbora. Kao odgovor na ovu meru smenjeni članovi su pokušali da sazovu sopstveni kongres, ali se tada iz beogradske centrale Udruženja kao mera zatražila intervencija Ministarstva unutrašnjih dela, kao i oduzimanje činova izbačenim rezervnim oficirima. ${ }^{48}$ Znatno ozbiljniji sukob izbio je aprila 1933 , kada je Uprava grada Beograda imenovala komesara Udruženju rezervnih oficira i ratnika posle rasplamsalog unutrašnjeg sukoba i prelivanja ovog obračuna u dnevnu štampu. ${ }^{49}$ Uprava Udruženja je optuživana od dela članstva da se u Udruženju vrše velike pronevere, da su članovi izbacivani iz Udruženja shodno simpatijama ili antipatijama Milana Radosavljevića i njegovih najbližih saradnika. Iskrslo je i pitanje Fonda za podizanje Invalidskog doma, jer je Radosavljević bio i visoki funkcioner Udruženja invalida. Deo optužbi ticao se i finansiranja Ratničkog doma, kao i manipulacija sa članskim uplatama i donacijama. Komesarsko upravljanje Udruženjem dovelo je do podnošenja nekoliko desetina krivičnih prijava protiv bivšeg predsednika i njegovih saradnika. Prvi komesar bio je general u penziji Joksim Gajić, a nasledio ga je Petar A. Kočić, da bi tek krajem 1937. godine bio zakazan skup na kome je izabrana nova legalna uprava.

Tada je za predsednika izabran inženjer Nikodije Bogdanović, ${ }^{50}$ dok je mesto sekretara preuzeo novinar Dobrivoj M. Stojadinović. Od svog izbora nova

cija je osnovana 25. novembra 1918. sa sedištem u Parizu, a članovi su mogle da bude samo zemlje ratne pobednice. - Трећи годишии конгрес Међусавезничке Федераиије ратника, Ратнички гласник, 2, I, 1923, 7.

46 Записник седниче Управног Одбора Средишње Управе Удружења Резервних Офииира и Ратника одржане на дан 18. марта 1932. године у Ратничком Дому у Београду, Ратнички гласник, IV, Београд 1932, 164.

${ }^{47}$ Са Гучевске прославе, Ратнички гласник, 9, IX, 1930, 352.

${ }^{48}$ ИАБ, 1027. „Књига записника са седница Управног одбора и Средишне Управе Удружења резервних официра и ратника од 24. 8. 1928 - 2. 8. 1929“, 22, Седница одржана 12. септембра 1928.

${ }^{49}$ Изјава чланова Средишње управе Удружења резервних официра и ратника у Београдy, Ратнички гласник, III, Београд 1933, 102. - Država se umešala u spor Udruženja po više osnova. Najpre, ona je preko zajmova u Hipotekarnoj banci bila uključena u podizanje Ratničkog doma, ali je primenila i članove Zakona o unutrašnjoj upravi kao i Zakona o udruženjima. IAB, 1027, K-17. „Prijava protiv Mihajla Simića Državnom tužiocu okružnog suda za grad Beograd“", 22. jul 1933.

${ }^{50}$ Nikodije Bogdanović je završio u 33. generaciji Vojnu akademiju. Među članovima nove uprave nalazili su se: Slavko Šajković, Steva Popović, David Albala, Branko Fabković, Dragoljub Todorčević, Ladislav Bevc, Ika Panić. 
uprava skrenula je aktivnosti Udruženja ka ispunjenju socijalnih zahteva bivših ratnika. ${ }^{51}$ Nameravana je i unutrašnja reforma organizacije, kako se ponovo ne bi došlo u situaciju da čitava organizacija zavisi od male grupe ljudi koji je vode, kao i od njihovih privatnih veza i uspeha. ${ }^{52}$ Zatečeno je i nekoliko sudskih sporova. Najpre, proces sa arhitektom Verhovskim u vezi sa nadzorom koji je vršio prilikom izgradnje Spomenika braniocima Beograda na Novom groblju, kao i izvođačima Ratničkog doma. ${ }^{53} \mathrm{~S}$ druge strane, protiv bivše uprave vođen je niz sudskih procesa, pa je Milan Radosavljević odlukom Kasacionog suda osuđen 1939. godine na 11 godina zatvora. ${ }^{54}$ Još jedan problem koji je sputavao rad Udruženja bio je dug prema Vojno-tehničkom zavodu, a odnosio se na livenje Spomenika braniocima Beograda. ${ }^{55}$ Niz nabrojanih problema ukazivao je da brojni poduhvati koje je započeo Milan Radosavljević nisu bili do kraja promišljeni, kao i da su prevazilazili finansijske mogućnosti Udruženja.

Izgradnja Ratničkog doma predstavljala je umnogome najambiciozniji projekat Udruženja, a grandioznost objekta opterećivala je na izvestan način i novo rukovodstvo. Naime, iako je objekat dovršen 1931. godine, nije bila iskorišćena čitava površina parcele koju je Beogradska opština dodelila na korišćenje Udruženju odlukom od 19. marta 1927. Zanimljivo je da je opštinska odluka obrazložena kao znak zahvalnosti Opštine bivšim borcima. ${ }^{56}$ Preostalih 1500 kvadrata ostajalo je neiskorišćeno i posle 1932. godine, a prema ugovoru sklopljenom sa Beogradskom opštinom, Udruženje je moglo da izgubi ovo zemljište ukoliko ga ne iskoristi. ${ }^{57}$ Zbog toga je nova uprava, uz podršku princa Pavla Karađorđevića, odlučila da krene u još jedan ambiciozan građevinski poduhvat i time zaokruži celinu Ratničkog doma.

${ }^{51}$ „Invalidska knjižica išarana pečatima ustanova koje su davale trenutnu pomoć od 10 do 50 dinara ratniku bez cele noge, izvučene iz kuka - jedini je dokument dokaza o prošlosti koja se tako bolno sudara sa brutalnošću sadašnjosti.“ - Добривој М. Стојадиновић, Наш глас, Ратнички гласник, 16, I, 1937, 18.

52 Добривој М. Стојадиновић, Озбиљни и тешки задаци намег Удружења, Ратнички гласник, 16, II-III, 1937, 228.

${ }^{53}$ Извештај средишње управе, Ратнички гласник, 19, V, 1940, 258.

${ }^{54}$ ВА, ДПП, К-1473, 119.

55 Зидање нове зграде Ратничког Дома и стање зајмова, Ратнички гласник, 19, V, 1940, 300. - Usled krize i uvođenja komesarske uprave Udruženje nije dovršilo uređivanje vojničkog groblja u Tijeu pored Pariza, a problemi su izbili i u Kraljevu, gde je zaustavljeno podizanje centralnog gradskog spomenika zbog opstrukcije predsednika lokalnog odbora Udruženja, Voje Radosavljevića, brata nekadašnjeg predsednika Milana Radosavljevića. Na ovaj način obračun unutar Središnje, beogradske, uprave preneo se na nekoliko srpskih gradova i odrazio se na sve nezavršene poduhvate. Tako su u pismu kraljevačke opštine tražili pomoć od nove uprave koja je vodila rezervne oficire: „Dakle radi njihovog nesporazuma spomenik stoji već pet godina nedovršen na opštu sramotu naše varoši, a i cele otadžbine i ako - ponavljamo - kredit postoji za dovršenje." - IAB, 1027, K-18. Opština varoši Kraljevo Središnjoj upravi, 8. februar 1939.

56 Зидање нове зграде Ратничког Дома и стање зајмова, Ратнички гласник, 19, V, 1940,276 ; ИАБ, 1027, К-20. „Уговор о закупу без накнаде“.

${ }^{57}$ ИАБ, 1027, К-20. „Уговор о закупу“. 
Budući da prostorije koje su se izdavale u okviru Ratničkog doma nisu donosile željeni prihod, verovalo se da bi se Dom mogao dograditi hotelom, čime bi se dugoročno obezbedila i sredstva za nameravanu naglašeniju socijalnu politiku Udruženja. Kredit za dogradnju Doma dobijen je, posle više trzavica, kod Poštanske štedionice. Izgrađen je hotel sa nekoliko desetina soba kao i Klub za rezervne oficire. ${ }^{58}$ Troškovi su međutim premašili očekivanja, pa se Udruženje ponovo našlo u dugovima. ${ }^{59}$ Konačno, vlada je 31. marta 1940. donela odluku da preuzme otplatu duga Udruženja. ${ }^{60}$ Bez obzira na pokušaje da se Udruženje i njegov rad dovedu u uređeno stanje Ministarstvo vojske i mornarice je iznenada razrešilo postojeću upravu i ponovo imenovalo komesara, ovoga puta Milivoja V. Purića. Odluka je doneta bez ikakvog objašnjenja članstvu, uz krajnje šturo saopštenje, ali je moguće da je finansijsko poslovanje i ovoga puta činilo pozadinu postupka. ${ }^{61}$

Tokom 1940. godine ostvarena je dosta uspešna saradnja sa ministrom vojske i mornarice, generalom Milanom Nedićem. Rat koji je izbio u Evropi menjao je i ulogu rezervnih oficira. U ovom periodu Udruženje je posmatrano pre svega kao još jedna odbrambena snaga zemlje. ${ }^{62}$ Predstavnici pododbora iz pograničnih krajeva žalili su se Upravi „,da su manjine digle glavu“, kao i da se u pojedinim krajevima stvara utisak da će te teritorije biti vraćene državama kojima su pripadale pre 1918. godine. ${ }^{63}$ Otvarajući novoizgrađene prostorije Ratničkog doma, opasnost od novog rata pomenuta je i u govoru generala Nedića kada je naglasio neophodnost praćenja modernog razvoja tehnike i stalnog vojnog usavršavanja rezervnih oficira. ${ }^{64}$

$\mathrm{U}$ isto vreme, prvi put, postignut je i značajan napredak u saradnji sa drugim organizacijama sličnog tipa. Time je konačno omogućeno formiranje Saveza

58 Свечано освећење другог дела Ратничког Дома Удружења рез. офичира и ратника, Ратнички гласник, 19, I, 1940, 39; Нови хотел ратничког дома, Ратнички гласник, 20, I, 1941, 59.

${ }_{59}$ Стари ратник, Свечано освећење другог дела Ратничког дома и клуба Резервних официра, Ратнички гласник, 19, II, 1940, 107.

60 Зидање нове зграде Ратничког Дома и стање зајмова, Ратнички гласник, 19, V, $1940,283$.

${ }^{61}$ Jedina smernica za postupke vlasti može se naći u optužbi da se uprava Udruženja nije pridržavala pravila. - „Реч комесара Удружења“, Ратнички гласник, 19, X, 1940, 553.

${ }^{62}$ Стари ратник, Говор Министра војске и морнарице арм. генерала Г. М. Недића, Ратнички гласник, 19, II, 1940, 110. - General Nedić je izdao naređenje da se pomaže formiranje odbora Udruženja svuda u Jugoslaviji. Tokom 1940. godine predstavnici Udruženja razmišljali su da svoju organizaciju omasove putem obaveznog članstva za sve rezervne oficire. - „Зидањье нове зграде Ратничког Дома и стање зајмова“, Ratnički glasnik, 19, V, 1940, 300; Pomoć generala Nedića ogledala se i u izlasku u susret rezervnim oficirima prilikom isplate troškova u slučajevima poziva na vojne vežbe. Ovakvi boravci u jedinicama su se ustalili tokom 1940. godine.

${ }^{63}$ Извештај средищње управе, Ратнички гласник, 19, V, 1940, 248.

${ }^{64}$ Исто, 111. - Iste večeri kada je novi deo Doma osvećen, Mihajlo Švabić je između ostalog konstatovao opštu atmosferu: ,Još nismo stigli da se rasteretimo poratnih tegova posle sedmogodišnjeg ratovanja, a već na sve strane čujemo novu ratnu hajku...". - Ст. Јовановић, Другарско вече, Ратнички гласник, 19, II, 1940, 115. 
ratničkih udruženja Kraljevine Jugoslavije. ${ }^{65}$ Ovo je bio značajan uspeh, ali on je ostvaren u vreme kada je scena bivših ratnika bila bez mnogih uglednih ličnosti, kao i bez stabilne, moćne organizacije. Kontekst u kome je Savez konačno formiran veoma se razlikovao od onog iz prvih posleratnih godina. ${ }^{66}$ Veliki broj članica Saveza bile su organizacije koje su osnovali nekadašnji članovi Udruženja rezervnih oficira i ratnika. Ovakva rascepkanost svedočila je ne samo o nezadovoljstvu stanjem svojih prava i statusom među nekadašnjim srpskim oficirima i vojnicima, već i o složenosti i brojnosti ratnih događaja kroz koje je prošla srpska vojska tokom 1912-1918.

Naime, u Savezu ratnika bili su, pored Udruženja rezervnih oficira i ratnika, Udruženje ratnih invalida, Savez ratnih dobrovoljaca, Udruženje nosilaca Albanske spomenice, ${ }^{67}$ Udruženje branilaca Beograda, Udruženje nosilaca Karađorđeve zvezde sa mačevima, Udruženje penzionisanih oficira i vojnih činovnika, Udruženje đaka-ratnika, Udruženje nosilaca zlatne ili srebrne medalje za hrabrost, Udruženje nosilaca Belog orla sa mačevima, Društvo starih četnika i Udruženje rezervnih podoficira. Procenjivalo se da ova udruženja predstavljaju oko 300.000 bivših ratnika, ${ }^{68}$ ali je malo verovatno da su ove organizacije mogle zaista dopreti više od nekoliko desetina hiljada boraca.

Ratnu 1941. godinu rezervni oficiri u okviru Udruženja rezervnih oficira i ratnika dočekali su zabrinuto ${ }^{69}$ i razjedinjeno, ističući da osnovni materijalni ni moralni zahtevi bivših ratnika nisu rešeni. ${ }^{70}$ Istovremeno, kako se pritisak u Jugoslaviji povećavao, među članovima Udruženja počele su da se otvoreno iznose zamerke. Tokom 1940. godine planirani kongres u Ljubljani je otkazan uz primedbu „da su prilike takve da kongres ne može da se održi u Ljubljani““. ${ }^{71}$ Isticalo se i da se van Srbije ne gleda isto na ciljeve Udruženja, već da se pre svega zanima za prava rezervnih oficira, dok je mesto starih ratničkih tradicija gubilo svoj

${ }^{65}$ Савез ратничких удуржења Краљевине Југославије, Ратнички гласник, 19, II, 1940,88

${ }^{66}$ Савез Ратничких Удружења, Ратнички гласник, 4, II, 1925, 33.

${ }^{67}$ Rezervni oficiri su naročito pratili sa zebnjom brz porast broja članova ovog udruženja jer je u njemu naglašavana uloga običnih vojnika koji su čak birani na rukovodeća mesta u upravi. Takođe, među članovima ovog udruženja primećen je i određeni otpor prema oficirima kao članovima. - IAB, 1027. K-19. Pismo pododbora Kruševac od 25. jula 1938. upućeno predsedniku Udruženja rezervnih oficira i ratnika Dobrivoju Stojadinoviću.

${ }^{68}$ Isto.

69 „Najzad, sa tradicionalnim željama o novoj godini, pozdravljam i sve drugove i članove njihovih porodica prisutne u ovom Domu, kao i otsutne drugove, koji novo leto dočekuju sa svojim vojnicima, vršeći službu prema Kralju i Otadžbini. A što se tiče događaja, koji nam u novoj godini idu u susret, mi za njih imamo samo ono rezonovanje, koje je tako viteški izraženo u pesmi našeg slobodarskog pesnika, a to je: Nek robuje, ko ropstvom duguje, koji život, u ropstvu poštuje. Živeli." - Резервни официри Краљевине Југославије на почетку 1941 године, Ратнички гласник, 20, II, 1941, 61. - Tokom 1941. godine problem za normalan rad Udruženja predstavljale su i zabrane okupljanja koje su tada bile na snazi.

70 Добросав М. Стојадиновић, Начело сарадюе, Ратнички гласник, 20, II, 1941, 72-73.

71 Записник пленарне седнице, Ратнички гласник, 19, VI, 1940, 369. 
prioritet u skladu sa promenom odnosa starih srpskih i novih jugoslovenskih rezervnih oficira. ${ }^{72}$

Poslednje dane Kraljevine Udruženje je, i dalje sa Komesarom na čelu, dočekalo nesposobno za značajniju akciju. Kongres na kome je trebalo da bude izabrana nova uprava bio je zakazan za 23. mart 1941. godine. Ratnički glasnik u kome bi bile objavljene odluke kongresa nikada nije odštampan jer su martovski događaji prekinuli sve pokušaje povratka ovog udruženja na javnu scenu. ${ }^{73}$

Opstajanje problema tokom čitavog funkcionisanja Udruženja pokazuje neuspeh u rešavanju ratničkih pitanja poput njihovog materijalnog i moralnog statusa, lečenja, zaposlenja ili školovanja dece. Stečene privilegije morale su se uvek iznova osvajati i obnavljati. S druge strane, Udruženje je bilo previše usmereno ka zaštiti prava rezervnih oficira, zbog čega ova organizacija nikada nije privukla veći broj običnih vojnika. Posebnu teškoću predstavljao je i problem centralizma na kojem je ovo udruženje bilo utemeljeno, a koji je vodio ka gubitku sistematičnosti i kontinuiteta u radu prilikom slučajeva krize i gubitka poverenja u upravu poput onog iz 1933. godine. Na kraju treba istaći i da je potreba za nastajanjem veteranskih organizacija u svim zemljama koje su učestvovale u Svetskom ratu, pokazivala da se odnos između države i mobilisanih građana promenio. O tome je svedočila i konstanta u ratničkim zahtevima, a to je da se odnos boraca i države jasno definiše kako bi se u budućim ratovima izbegle iste posleratne teškoće.

Danilo Šarenac

\section{SOCIETY OF THE RESERVE OFFICERS AND WARRIORS 1919-1941}

\section{Summary}

The article explores the activity of the Society of the Reserve Officers and Warriors which functioned from 1919 until 1941. This society at first represented most of the veterans of the former Serbian army, but gradually this organization expanded their activities also on Croatia and Slovenia accepting some of the ex Austro-Hungarian officers. In time the Society attracted the newly formed reserved officers, the ones just coming out of the Yugoslav army schools. The Society of the Reserve Officers and Warriors had a whole range of activities including various commemorations regarding the Great War and other Serbian military traditions. Also, they were fighting for improvement their material status and moral respect. Consequently, they managed to build several ossuaries and monuments as well as the monumental building called the Warriors Hall. One of the successes was also the appropriate treatment of the years spent in the war regarding the peacetime career progress or pension benefits. Nevertheless, due to the centralized way of functioning and overambitious projects this society suffered a crippling blow which manifested itself in 1933 with the culmination of the management's internal conflicts and finally had its epilogue in the introduction of the special state's supervisor, who acted as the president of the organization. By the March of 1941 the Society tried for several times to regain its strength, nevertheless during the last days of the Kingdom the organization was still under tutelage and was far less powerful then it was in the $1920^{\mathrm{s}}$. Thus, the work of this organization shows that the presence of the veteran groups in public was one of the war's consequences and regarding the work of this particular society, its history shows all the setbacks in the Yugoslav treatment of this type of war legacy.

\footnotetext{
${ }^{72}$ Исто, 75.

${ }^{73}$ Мил. С. Пурић, Ванредни конгрес, Ратнички гласник, 20, III, 1941, 115.
} 